\title{
STANDARDIZATION OF KI-67 AS A BIOMARKER OF CELL PROLIFERATION
}

\author{
Zhylkibayev A.A., Sarina N.I., Mun E.A, Eskendirova S.Z. \\ National Center for Biotechnology, \\ 13/5, Korgalzhyn road, Nur-Sultan, 010000, Kazakhstan \\ saule_e@mail.ru
}

\section{ABSTRACT}

Currently, the most informative, accessible and common method for evaluating the level of cell proliferative activity is identification and quantification of Ki-67 protein as aniversal proliferation biomarker. The Ki-67 antigen is a component of the nuclear matrix, and nuclear core localization changes are observed during the cell cycle. Ki-67 protein is mainly associated with the chromosomes and belongs to the family of perichromonucleic proteins that surround chromosomes during mitosis. Ki-67 is characterized as a large nuclear protein based on cloning and sequencing a cDNA library. It is subjected to conformational changes during the cell cycle. Ki-67 also undergoes post-translational modifications by phosphorylation, accompanied by redistribution from the nucleoplasm into the perichromosomal layer and back during mitosis. Accordingly, Ki-67 is a widely used biomarker for cancer cells, including for pathological diagnosis and monitoring treatment responses. In particular, determination of the expression level of Ki-67 plays an important role in distinguishing the molecular subtypes of breast cancer and is one of the main criteria for determining the appropriate scheme of chemotherapy. However, there is currently no standardization of evaluation methods for predicting the disease outcome and effectiveness of chemotherapy. Researchers have reported the high variability in the Ki-67 index between different laboratories, depending on the choice of primary antibodies, methods for conducting immunohistochemistry, and methods for quantifying expression.

The most appropriate threshold values of Ki-67 expression for clinical monitoring are continuously debated, and determination of a single cut-off point of Ki-67 was shown to not appropriately reflect the heterogeneous biology of the disease. In accordance with the latest recommendations of the St. Gallen conference of 2015, low, medium, and high Ki-67 thresholds were identified to achieve a better response to therapy. Here, we discuss the structure and function of the protein, as well as progress toward achieving a standardized determination method of Ki-67.

Key words: Ki-67 biomarker, cell proliferation, proliferation activity, breast cancer, protein expression, immunohistochemistry

\section{INTRODUCTION}

In modern oncomorphology, criteria for verification of histological and biological transformation degree of cells with maximum objectivity are constantly being searched. The particular attention of the researchers is attracted by the study of cell proliferation as a fundamental biological process, as well as a specific property of a transformed cells population that determines the course of malignant disease.

Proliferative activity (PA) is a leading factor in the mechanism of malignant cell transformation and in the biological behavior of already arisen tumors. Changing the process of proliferation is a fundamental process in carcinogenesis, which determines the clinical course and prognosis of the disease. This is 
one of the most important characteristics of the tumor phenotype, which largely determines the growth rate of the neoplasm, the risk of metastasis, the potential response to remedial measures and the outcome of the cancer. Many factors affecting the course and outcome of oncological diseases are mediated through a change in proliferative activity $[1,2]$.

One of the key concepts of PA that researchers operate is the cell cycle, which also called mitotic or proliferative cycle. At present, the most convenient designation of cell cycle is the interval between the completion of mitosis in the original cell and that in its daughter cell.

The most informative, accessible and common method for evaluation of the cell proliferative activity level is the identification of a universal biomarker - Ki-67. This antigen was described for the first time by Gerdes et al. in 1983 as the main part of the nuclear matrix associated with the chromosomes in the mitotic phase [3]. The detected protein was named after the University of Kiel (Kiel) and by the new clone №67 of isolated monoclonal antibodies $(\mathrm{mAb})$. Studies on the interaction of this $\mathrm{mAb}$ with normal tissue cells, mitogen-stimulated lymphocytes of peripheral blood and cells induced to differentiate showed that the Ki-67 antigen is expressed in proliferating, but not in resting cells.

Morphological studies of proliferating cells have shown that the Ki-67 antigen is a component of the nuclear matrix, and changes in its intranuclear localization are observed during the cell cycle. Ki-67 protein is detected in proliferating cells in all active phases of the cell cycle - G1, S, G2, M. The intracellular localization and distribution of Ki-67 varies with the transition from one phase of the cell cycle to another. Ki-67 was found in the nucleoli in the middle of the G1 phase. In subsequent S- and G2-phases $\mathrm{Ki}-67$ protein was determined in both, the nucleoli and the karyoplasm. After the nuclear membrane is disintegrated (in mitosis phase), the distribution has a diffuse character and repeats of the condensed chromatin pattern. In metaphase, protein is detected on the surface of individual chromosomes in the form of granules. The protein is not detected at the G0 point of the cell cycle, nor at the first phase of the cell cycle at the beginning of G1. The amount of Ki-67 antigen steadily increases from the middle of the G1 phase to the $\mathrm{M}$ phase, reaching a maximum during the metaphase of mitosis. The amount of Ki-67 in cells begins to decrease rapidly in anaphase and telophase of mitosis [4-6].
The appearance of Ki-67 coincides with the entry of the cell in mitosis, which allows it to be used as a universal marker of proliferation in the evaluation of malignant tumors. The immunohistochemically positive reaction to $\mathrm{Ki}-67$ shows that the cell is in the interval state from the late G1 phase to the M phase. $\mathrm{Ki}-67$ is expressed in the cell nucleus during the G1, S, G2 and M phases of the cell cycle, but not in G0. Upon transition of the cell after mitosis to the G0 phase, the Ki-67 antigen rapidly undergoes catabolism and ceases to be detected in the nuclei of interphase cells [4-8]. However, it was shown that Ki-67 protein is not detected only in actively proliferating cells, but also in cells where the p53 and p 21 is overexpressed, which causes the blocking of replication or DNA damage [5].

The half-life of Ki-67 protein from 60 to $90 \mathrm{~min}$ utes, allow researchers to assume that its synthesis and disintegration are under very precise control. An increase in the amount of Ki-67 protein in cells is associated with its well-regulated de novo synthesis and an efficient degradation process [4-8]. Thus, the Ki-67 protein is mainly associated with detected chromosomes in the telomere and centromere regions and belongs to the family of perichromonucleic proteins surrounding chromosomes during mitosis.

The Ki-67 antigen is presumably attributed to regulatory proteins since its appearance coincides with the moment when the cell enters to the mitotic cycle. It was shown that microinjection of antibodies to Ki-67 leads to a decrease in cell proliferative activity. Ki-67 antigen is a short-living protein, which collapses within 1,5-2 hours. Since it does not have time to accumulate and does not remain in dormant cells, antibodies to Ki-67 recognize only dividing cells. It is very labile and gets destroyed within 1,5-2 hours in the presence of proteases, which makes it difficult to study. Therefore, connection with proteins regulating the cell cycle is poorly understood and is not clearly defined [4-8].

Recent studies have shown that Ki-67 protein performs a number of functions during mitosis, but the specific role in the process of cell division is still unknown. In particular, Ki-67 is responsible for the attachment of chromosomes to the nuclear membrane in mitosis prophase (in case of its deficiency, chromosomes condense into separate bodies). In addition, Ki-67 protein prevents chromosomes from sticking together into a single chromatin mass after the dissolution of the nuclear membrane, thus ensuring the independent movement of each chro- 
mosome and its precise interaction with the spindle of division. With a lack of Ki-67, the formation of metaphase plates is disturbed, and the cells almost never enter into anaphase. However, it should be noted that even though chromosomes form a single conglomerate with the lack of Ki-67, their internal structure remains intact $[4-6,9]$. Although $\mathrm{Ki}-67$ is not a part of the internal structure of mitotic chromosomes, and its deficiency leads to defects in the assembly of nucleolus after mitosis and the disruption of interphase heterochromatin $[5,10]$. In case of Ki-67 overexpression, the ectopic regions, containing heterochromatin are formed in the human cells. The Ki-67 protein is not only involved in the formation of heterochromatin, but also in the ribosome biogenesis and in the synthesis of rRNA $[4-6,9,10]$.

The structure and functions of the Ki-67 protein The gene encoding Ki-67 protein (MKI67) is located at the 25th locus of the long arm of chromosome 10 (10q25-ter), and the expression of this gene is absolutely necessary for the implementation of cell proliferation. By cloning and sequencing a cDNA library, Ki-67 protein is characterized as a large nuclear protein, subject to pronounced conformational changes during the cell cycle. The nuclear antigen $\mathrm{Ki}-67$ is a dimeric molecule and is a nonhistone protein that exists in two isoforms - with a molecular mass of $395 \mathrm{kD}$ (consists of 3256 amino acids) and $345 \mathrm{kD}$ (consists of 2896 amino acids).

Schluter et al. (1993) determined the full length of nucleotide and amino acid sequences of the Ki-67 protein [11] for the first time. The entire Ki-67 gene locus is represented by 29965 base pairs located in the long arm of the chromosome 10 (10q25-ter). In figure 1 shown that this gene consists of 15 exons (from 67 to 6845 base pair) and 14 introns (from 87 to 3569 base pairs).

\section{MKI67}

exon

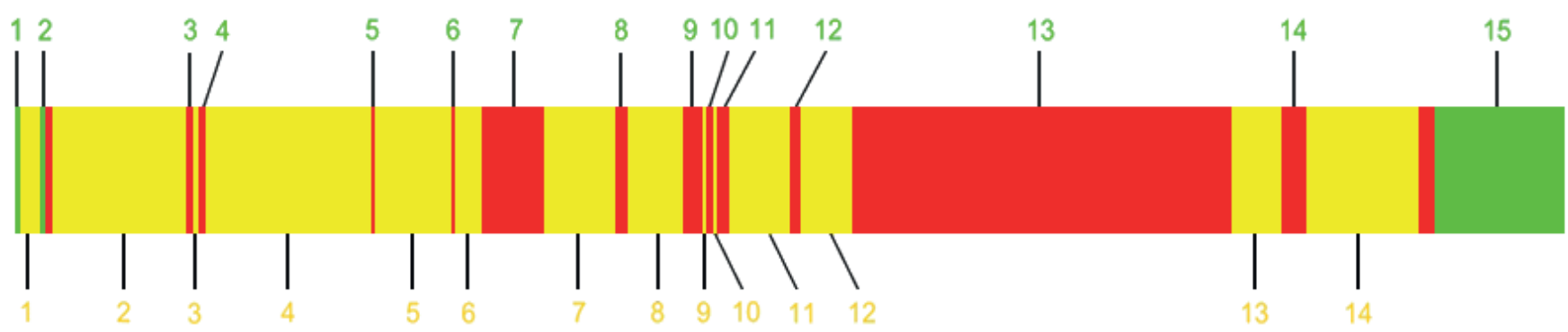

intron

\begin{tabular}{|lll|ll|}
\hline Exons & Length & Coding/UTR & Introns & Length \\
1 & 106 & UTR & 1 & 342 \\
2 & 181 & UTR/92 & 2 & 2406 \\
3 & 79 & 79 & 3 & 94 \\
4 & 116 & 116 & 4 & 3561 \\
5 & 67 & 67 & 5 & 2716 \\
6 & 46 & 46 & 6 & 483 \\
7 & 1080 & 1080 & 7 & 1325 \\
8 & 176 & 176 & 8 & 981 \\
9 & 313 & 313 & 9 & 87 \\
10 & 119 & 119 & 10 & 1111 \\
11 & 172 & 172 & 11 & 954 \\
12 & 156 & 156 & 12 & 877 \\
13 & 6845 & 6845 & 13 & 2002 \\
14 & 444 & 444 & & \\
15 & 2597 & $66 /$ UTR & & \\
\hline
\end{tabular}

Fig. 1. Gene structure of Ki-67 biomarker [12]

Two isoforms of the Ki-67 protein with a mass of 345 and $395 \mathrm{kDa}$ originate from alternative splicing, these isoforms differ from each other by the presence or absence of the fragment encoded by exon 7 (figure 2). 
Long type mRNA containing the 7th exon

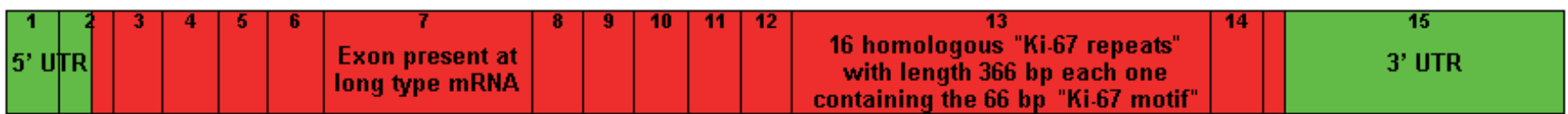

Short type mRNA missing the 7th exon
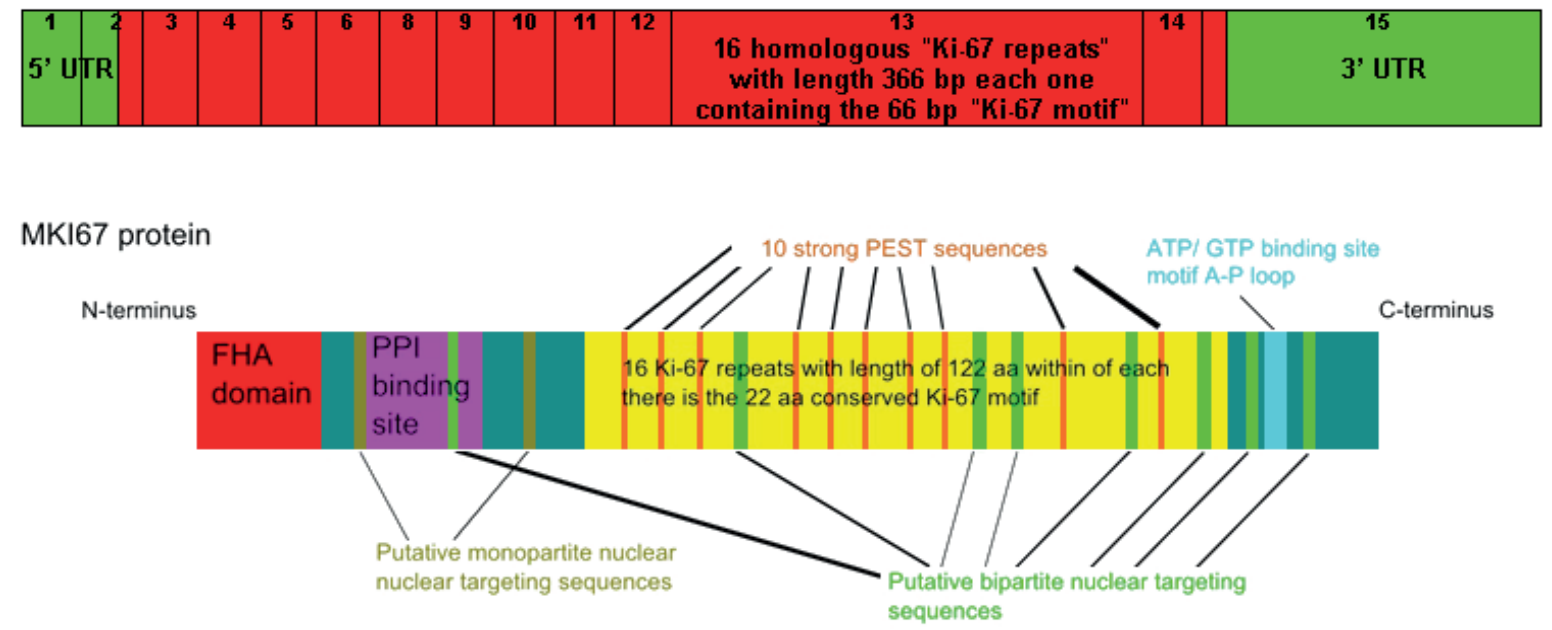

Fig. 2. mRNA and protein structure elements of Ki-67 [12].

The phosphopeptide-binding FHA (Forkhead - assocoated) domain and binding site for protein phosphatase I (PP1) are located on the N-terminus of the Ki-67 protein. This is followed by a conservative domain (CD domain) of 31-amino acids with an unknown function and a Ki-67 domain consisting of 16 repeats. The $\mathrm{C}$-terminus of the $\mathrm{Ki}-67$ is enriched with pairs of leucine and arginine residues (LR-domain). Ki-67 has an amphiphilic structure: its short C-terminus has affinity to chromatin, and the long $\mathrm{N}$-terminus, in turn, repels itself from chromatin and has an affinity to cytoplasm [6,13-15]. The main structural feature of the Ki-67 protein is the presence within the largest 13 exons ( 6845 base pairs) of multiple repetitive elements (14 in mice, 16 in humans), consisting of 122 amino acids in length with 43-62\% homology. Within these "Ki-67 repeats", there is a highly conservative 22 amino acid region known as the "Ki-67 Motif" with 90-100\% identity.

Despite the fact that the primary structure of the Ki-67 antigen is currently studied well, the function of this protein is still unclear. This is due to the fact that Ki-67 protein has a high molecular weight and high sensitivity to the action of proteases, and there are no homologous proteins with a known function.

Ki-67 has a number of structures similar to proteins involved in the regulation of the cell cycle. Such structures include potential phosphorylation sites for various kinases (143 sites for protein kinase C, 89 sites for casein kinase II, 2 sites for tyrosine kinase, proline-glutamine-serine-threonine (PEST) -sequence (available in many short-lived regulatory proteins), domain for binding with the replication fork - ATP/ GTP binding site motif A-P loop [4-6,11-15].

Currently, there is no consensus on the role of Ki-67 protein during the cell cycle. Two main hypotheses were put forward regarding the role of Ki67: the first is that it is a protein-regulator of the cell cycle, the second is that it is a DN-associated protein necessary for the organization of DNA structure. Numerous experiments have convincingly shown that Ki-67 is vital in cell mitosis, and that when it is neutralized, cell mitosis stops [5-8]. It is known that cell does not enter into mitosis in case of repression of the gene transcription encoding Ki-67. In a number of works in recent years, some functions of Ki-67 have been proposed and justified. Takagi et al. described the structural function of Ki-67, according to which it externally supports the shape of chromosomes during mitosis [16]. While another group of researchers justified the functioning of Ki67 protein as a "surfactant" that prevents condensed chromosomes from sticking during mitosis [10]. This speaks in favor of the fact that $\mathrm{Ki}-67$ forms a steric and electrostatic barrier preventing chromosomes from "sticking" together. In confirmation of this, high density of Ki-67 was found on chromosome surfaces using fluorescence spectroscopy, and when applying 
a double tag on both ends of the Ki67 protein, an extended brush-like molecular conformation was detected as a characteristic of polymer surfactants. It has been shown that Ki-67 undergoes post-translational modifications by phosphorylation, accompanied by a marked redistribution of $\mathrm{Ki}-67$ from the nucleoplasm into the perichromosomal layer and back during mitosis [4-10]. Ki-67 becomes functionally active as a result of changes in chemical characteristics due to its phosphorylation. The change in phosphorylation status determines the ability of Ki-67 to bind with many intracellular components. Massive phosphorylation of Ki-67 occurs when a cell transitions from G2 to the M phase. Ki-67 phosphorylation and dephosphorylation is controlled by key regulatory mechanisms of the cell cycle and takes place during the two main events of cell division: disintegration and reorganization of the nucleus during mitosis [17-19]. Ki-67 is a direct substrate of cyclin-dependent kinase 1 (CDK-1) [18].

A significant amount of data was obtained in experiments on cell cultures to understand the physiological role of Ki-67. A wide range of proteins, which Ki-67 can interact with, were identified as a result of the research. These include ribosomal proteins, DNA helicases, regulatory proteins, various signaling molecules $[9,10,19]$.

Standardization and validation of the determination method for the expression of Ki-67

Determination of KI67 expression based on immunohistochemical analysis (IHC) is one of the most reliable indicators of the proliferative activity of tumor cells in breast cancer (BC). Determination of the expression level of Ki-67 plays an important role in the differentiation of the molecular subtypes of breast cancer and is one of the criteria for determining the scheme of chemotherapy [20-23].

Increased expression of $\mathrm{Ki}-67$ is associated with a poor prognosis of breast cancer treatment and it is closely related to growth and invasion. In normal breast tissue, the expression level of $\mathrm{Ki}-67$ is very low. Ki-67 positive cases are more active in relation to growth, more aggressive in terms of invasion and are characterized by more pronounced metastasis. The high expression level of Ki-67 is associated with the recurrence rate and low overall survival of patients. Despite all the differences in the selection criteria, the design of the study, and the methodologies for measuring the threshold values of the Ki-67 level, the statistical significance and reliability of evalua- tion results are confirmed by a single-factor and a multifactorial analysis [24-27].

In 2009, at the conference on breast cancer in St. Gallen, Ki-67 was recommended as a biomarker for the prognosis and sensitivity of tumor cells to hormonal or chemotherapy [28]. However, despite the large number of studies conducted in the study of KI-67, today there is the problem of standardization of assessment methods that are necessary for the integration of biomarker in a long-term prediction of the outcome of the disease and the effectiveness of chemotherapy. To standardize the approaches in assessing the index of proliferative activity (IPA) for Ki-67 in patients with breast tumors, an international group was established in March 2010 [29]. The purpose of the working group was to define a general strategy for harmonization of methodological approaches to the unified assessment of IPA for Ki-67. In 2011, the Working Group published the guidelines on the validation of the pre-analytical and analytical stages of Ki-67 determination. The Guide also provided recommendations for the standardization of the post-analytical stage - evaluation, data analysis and interpretation of the results.

According to recommendations, the study of the expression of Ki-67 should necessarily be carried out on a surgical material, even if an immunohistochemical study of the biopsy material was performed before the start of the treatment. The results of the study may vary significantly for the biopsy and surgical material, especially in cases of heterogeneous staining of the tumor. To obtain reliable results, standardization of all stages of sample preparation is necessary: sample type, time from sampling to fixation, fixation type, fixation duration, material wiring, microtomy, storage of finished blocks and sections. A particular characteristic of the detection of the Ki-67 antigen is the need of an additional procedure of the thermal "unmasking" of antigen. The optimal results can be obtained when following the exact recommendation requirements of the protocol for immunohistochemical determination of Ki-67. Although Ki67 is tolerant to a variety of epitope extraction protocols, the action of protease and low $\mathrm{pH}$ should be avoided $[4,6,11,13,14,29]$.

The correct choice of the main immunoreagent, specific monoclonal antibodies, is extremely important during the analytical stage of detection. The reliability of the detection system of the obtained results is influenced by the sensitivity and specificity of primary antibodies. The antibodies used must be clini- 
cally validated, the test results must correlate with the outcome and prognosis of the disease. Concordance levels (coincidence of results) of the obtained results should be at least $90 \%$ and $95 \%$ for positive and negative results, respectively, compared to clinically validated methods for assessing Ki-67 expression.

$\mathrm{MAb}$ for Ki-67 protein was obtained for the first time by immunizing mice with an unpurified nuclear fraction of L428 cell line derived from the Hodgkin's lymphoma [3]. Ki-67 mAb detected two bands with a molecular mass of $345 \mathrm{kDa}$ and $395 \mathrm{kDa}$ on immunoblots. However, the original antibody Ki-67 was applicable for IHC only in fresh frozen material. The previously widely used $\mathrm{mAb}$ of the clone Ki-67 are rarely used, since they reveal an epitope of the antigen that is not resistant to formaldehyde fixation $[4,11,13,30]$. This problem was solved by obtaining monoclonal antibodies of the MIB series (Molecular Immunology Borstel) against the recombinant fragment of the Ki-67 protein [31]. After the development of the heat-induced epitope technique, mouse monoclonal antibodies were tested with reliable and reproducible results in formalin-fixed paraffin sections. It should be noted that MIB- 1 has the ability to detect an immunodominant epitope, the Ki-67 motif, unique to the Ki-67 protein (providing specificity), which is repeated 16 times in the protein (sensitivity increase) [32,33]. Therefore, an advantageous property of MIB-1 as an immunoreagent for IHC is in its constant and much better diagnostic efficacy.

Currently, various specific monoclonal and polyclonal antibodies to the recombinant peptide of Ki-67 antigen are being produced, which secrete proliferating cells that are in different phases of the cell cycle. Therefore, it is possible that different equivalents of Ki-67 antibodies recognize different epitopes that are expressed in different phases. For example, rabbit monoclonal antibody SP6 to Ki-67, which recognizes a similar Ki-67 epitope as MIB-1 in IHC [34], was successfully used. Ki-67 has only one test system based on 30-9 rabbit monoclonal antibodies (FDA approved 510k) for routine clinical diagnostics manufactured by Ventana Medical Systems (Tucson, Arizona, USA), ready for use without preliminary reaction conditions [36]. Although the list of known antibodies for immunohistochemical detection of Ki-67 is quite impressive, even the most frequently used MIB-1 has not yet been confirmed. Considering the long and proven track record of MIB1 monoclonal antibodies, it is considered as the "gold standard".
Researchers have reported high Ki-67 index variability between different laboratories, depending on the choice of primary antibodies, the immunohistochemichal method and the expression counting methods. The choice of Ki-67 antibody to use has a great effect on its index values. The significant differences in the detection rates between Ki-67 antibodies were found, despite the fact that identical microscopic fields were evaluated [36,37]. Scientists from the NordiQC group over the past years (2001-2016) have conducted research on the results of immunohistochemical (IHC) analysis of the proliferation marker Ki-67. 409 laboratories were involved in the last test. As a result of the test, the clones of monoclonal antibodies BS4, GM001, K2, MIB-1, UMAB107, 30-9 and SP6 were recommended for evaluation of Ki-67 expression. The Ventana system, based on the rmAb clone 30-9, was the most widely used analysis in this assessment and provided 99\% optimal estimates. The Dako system, based on the use of MIB-1 $\mathrm{mAb}$, showed $91 \%$ of positive ratings [37].

The most frequent reason for the variability of the results of immunohistochemical detection of Ki67 is the different interpretation of evaluation criteria. The introduction of a quantitative assessment instead of the traditionally adopted semi-quantitative scoring system (Allred) is a critical step in method application. The introduction of the Ki-67 IPA with the mandatory assessment of the percentage of positively stained cells in the daily practice of the anatomical department is associated with the problem of reproducibility of the quantitative assessment of IPA. The proliferative activity of the tumor is estimated as the percentage of Ki-67 positive cells from the total number of tumor cells with nuclear staining. Quantifying the expression level of the proliferation marker Ki-67 involves counting the proportion of stained nuclei among the nuclei of all tumor cells when counting at least 500 tumor cells, and the visual fields for counting are selected based on the highest mitotic activity.

Repeated attempts to standardize the methodological and technological approaches of assessing the proliferative activity of a tumor in clinical practice and the poor reproducibility of this feature in large studies with a sufficient number of participating laboratories have always led to the conclusion that it is necessary to validate the Ki-67 index in clinical studies [38-42]. Thus, the index of proliferative activity (IPA), defined as the percentage of Ki67 positive tumor cells, is an important marker in 
the diagnostics of breast cancer, because it is used to distinguish between luminal A-like (prognostically favorable) and luminal B-like (prognostically unfavorable) subtypes [20-23]. The threshold for the proportion of Ki-67-positive tumor cells, separating cases of breast cancer with high and low levels of proliferation, has changed over time. The threshold level of separation of IPA between these two groups is considered to be $14 \%$, where the luminal type A and $\mathrm{B}$ contain less or more than $14 \%$ of $\mathrm{Ki}-67-$ positive cells, respectively. It was later on accepted by the consensus of St. Gallen in 2011 for the use in routine clinical diagnostics [29] and underwent some changes at the conference in St. Gallen in 2013. A level of $\geq 20 \%$ to determine the luminal B-like subtype [39] was accepted by the most experts. In accordance with the latest recommendations of the conciliation conference in St. Gallen 2015, the assessed expression level of Ki-67 in 10\% of tumor cells and less is determined as low, more than $10 \%$ and less than $30 \%$ is intermediate, $30 \%$ and more is high. At the same time, a threshold value of $20 \%$ of stained tumor cells remains recommended for diagnostics. It also states that using of Ki-67 requires knowledge of local laboratory parameters and the minimum Ki67 value required for the "luminal B-like" subtype was $20-29 \%$ for the most of the panel. About onefifth of researchers stated that Ki-67 should not be used for this distinction [43].

Threshold levels are constantly under active discussion. Although the latest recommendations of ASCO (American Society of Clinical Oncology) also set a threshold of $20 \%$, some authors continue to use a threshold value of $14 \%$, believing that it better reflects the prognosis of the tumor and the response to therapy [44-46]. As part of a meta-analysis of Gepar Trio analyzing breast cancer samples and the outcome of the disease, it was shown that the definition of a single cut-off point Ki-67 does not reflect the heterogeneous biology of the disease. Instead, low, medium and high thresholds should be defined to achieve a better response to therapy [47]. Thus, the main problems in determining the expression level of Ki-67 are the adequacy of the IHC-study, and the correctness of the chosen method of calculation (objectivity, standard, reproducibility).

A number of professional communities, such as the European Society of Pathology (European Society of Pathology - ESP) and some guidelines recommend re-evaluating the Ki-67 index with the participation of a second expert opinion or using digital analysis of histological scans if the IPA is in the range of 10 to $35 \%$, the so-called gray zone [44-46]. Expert Panel Galen recommends that the researcher, when assessing Ki-67 for staining, focuses on the IPA median in the laboratory in order to increase reproducibility between researchers. Therefore, standardization of measurement of this indicator, regardless of the qualification of the pathologist and the level of the morphological laboratory, is necessary in therapeutic tactics. In connection with the development of digital imaging methods in morphology, new methods are proposed for evaluating IPA using digital image analysis (DIA) of scans of histological specimens. It is assumed that the automatic analysis of the Ki-67 index is a method that can replace the visual assessment of the IPA and improve the accuracy and reproducibility of the assessment. At the same time, the use of methods for the automatic analysis of drugs will reduce the time and the influence of human factor in the study of biopsy material [48].

Thus, the level of cell proliferative activity based on the detection of the Ki-67 biomarker can be used for morphological assessment of neoplasm malignancy degree as an additional criterion for diagnosing the tumor, and also as a predictor of the treatment efficiency.

\section{CONCLUSION}

One of the most important characteristics of malignant neoplasm is their growth potential. In this case disturbance of tumor cell proliferation mechanisms determines the aggressiveness and malignancy of the malignancy process. Uncontrolled proliferation in a tumor can be detected in several ways. For example, by counting figures of mitosis in tumor cells, including labeled nucleotides in DNA, followed by evaluation in a flow cytometer. In routine clinical practice, the most widely used practice is the study of cell proliferative activity, which is determined by the immunohistochemical method based on the nuclear antigen, Ki-67 protein. This protein is an accurate and optimal marker for the growth of the cell fraction, as it is expressed in highly proliferating, but not in resting cells. At present, the Ki-67 tumor marker is one of the most popular biomarkers in oncology and prevalent in the morphological assessment of the malignancy degree of the neoplasm. It serves as an additional criterion for diagnosing a tumor and as a predictor of treatment effectiveness. In Kazakhstan immunohistochemical (IHC) studies are performed in order to 
individualize the treatment of oncological patients at the laboratories level, including the assessment of cell proliferative activity based on the biomarker detection Ki-67.

Since immunochemistry plays an increasingly crucial role in oncology, scientists are trying to develop standardized methods for determination of Ki-67 protein level in normal and malignant cells. Distinguishing cellular proliferation activity is a key step in the treatment of cancer. Therefore obtaining domestic IHC products that reliably identify the Ki67 biomarker will allow them to be used in clinical practice for assessment of the proliferative activity of tumor cells. The introduction of the development will expand the range of domestic diagnostic tools.

\section{Acknowledgements}

This work was supported by the Ministry of Education and Science of the Republic of Kazakhstan (grant No. AP05133251 «Development of method for determining the Ki-67 biomarker for assessing the level of cell proliferation in malignant tumors» for 2018-2020 years).

\section{REFERENCES}

1. Whitfield M., George L., Perou G. Common markers of proliferation. Nature Reviews Cancer, 2006, vol. 6, pp. 99-106. PMID:16491069.

2. Berridge M. Cell Signalling Biology (Module 9. Cell Cycle and Proliferation). Portland Press Limited. 2014, 652 p. doi: 10.1042/csb0001009.

3. Gerdes J., Schwab U., Lemke H. et al. Production of a mouse monoclonal antibody reactive with a human nuclear antigen associated with cell proliferation. Int. J. Cancer, 1983, vol., no. 31,pp. 13-20. PMID:6339421

4. Scholzen T., Gerdes J. The Ki-67 protein: from the known and the unknown. J. Cell Physiol., 2000, vol.182, pp.311-322. PMID: 10653597

5. Sobecki M., Mrouj K., Camasses A.et al. The cell proliferation antigen $\mathrm{Ki}-67$ organises heterochromatin. eLife, 2016, vol. 7, no.5. 33p. doi: 10.7554/ eLife. 13722

6. Sun X., Kaufman P. Ki-67: more than a proliferation marker. Chromosoma. 2018, vol.127, no.2, pp.175-186. doi: 10.1007/s00412-018-0659-8.

7. Brown D., Gatter K. Ki67 protein: the immaculate deception? Histopathology. 2002. vol.40, no.1., pp.2-11. PMID:11903593
8. Endl E., Gerdes J. The Ki-67 protein: fascinating forms and an unknown function. Exp. Cell Res., 2000., vol.257, no.2, pp. 231-237. PMID:10837136

9. Cuylen S., Blaukopf C., Politi A.Z. et al. Ki67 acts as a biological surfactant to disperse mitotic chromosomes. Nature, 2016, vol.535., no. 7611, pp.308-312. doi:10.1038/nature 18610

10. Booth D., Takagi M., Sanchez-Pulido L.. et al. Ki67 is a PP1-interacting protein that organises the mitotic chromosome periphery // eLife, 2014, vol. 27, no.3. 19 p. doi: 10.7554/eLife.01641.

11. Schlüter C., Duchrow M., Wohlenberg C. et al. The cell proliferation-associated antigen of antibody Ki67: a very large, ubiquitous nuclear protein with numerous repeated elements, representing a new kind of cell cycle-maintaining proteins. J.Cell Biol.,1993, vol.123,no.3,pp. 513-522. doi :10.1083/ jcb.123.3.513

12. Atlas of Genetics and Cytogenetics in Oncology and Haematology, http://atlasgeneticsoncology.org/Genes/GC_MKI67.html

13. Duchrow M., Schlüter C., Wohlenberg C. et al. Molecular characterization of the gene locus of the human cell proliferation associated nuclear protein defined by monoclonal antibody Ki67. Cell Prolif., 1996, vol. 29, no.1, pp.1-12. PMID:8603106

14. Ross W., Hall P. Ki67: from antibody to molecule to understanding. J.Clin. Pathol. ,1995,vol. 48, no.3, pp. 113-117. doi: 10.1136/mp.48.3.m113

15. Gerdes J., Li L., Schlueter C. et al. Immunobiochemical and molecular biologic characterization of the cell proliferation associated nuclear antigen that is defined by monoclonal antibody Ki67. Am. J. Pathol., 1991, vol. 138, no.4, pp. 867-873. PMID: 2012175

16. Takagi M., Matsuoka Y., Kurihara T. Chmadrin: a novel Ki67 antigen-related perichromosomal protein possibly implicated in higher order chromatin structure. J. Cell Sci., 1999, vol. 112,no.15, pp. 2463-2472. PMID: 10393802

17. McCallum D., Hall P.A. Biochemical characterization of pKi67 with the identification of a mitotic-specific form associated with hyperphosphorylation and altered DNA binding. Exp Cell Res.,1999, vol. 252, no. 1, pp. 186-198. doi:10.1006/ excr.1999.4600

18. Endl E., Gerdes J. Posttranslational modifications of the KI-67 protein coincide with two major checkpoints during mitosis. J. Cell Physiol., 2000, vol.182, no.3, pp. 371-380. PMID:10653604

19. Scholzen T., Endi E., Wohlenberg C. et al. 
The Ki-67 protein interacts with members of the heterochromatin protein 1 (HP1 ) family: a potential role in the regulation of high-order chromatin structure. J. Pathol., 2002, vol.196, no.2, pp. 135-144. doi:10.1002/path.1016

20. Yerushalmi R., Woods R., Ravdin P. et al. Ki67 in breast cancer: prognostic and predictive potential . The lancet oncology., 2010, vol. 11, no.2, pp. 174-183. doi: 10.1016/S1470-2045(09)70262-1

21. Mannell A. The role of Ki-67 in breast cancer S. Afr. J. Surg., 2016, vol.54, no.2, pp.10-13. PMID:28240498

22. Ragab H., Samy N., Afify M. et al. Assessment of Ki-67 as a potential biomarker in patients with breast cancer. J. Genetic Engineering and Biotechnology. 2018, vol. 16, no.2, pp. 479-484. doi: 10.1016/j.jgeb.2018.03.002

23. Kheirandish S, Homaee F. Ki67- protein: a proliferation index in breast cancer. Rev Clin Med., 2015, vol.2,no.4,pp. 205-208. doi: 10.17463/ RCM.2015.04.010

24. Stuart-Harris R., Caldas C., Pharoah P. Proliferation markers and survival in early breast cancer: a systematic review and meta-analysis of 85 studies in 32,825 patients. Breast, 2008, vol.17, no.4, pp.323334. doi: 10.1016/j.breast.2008.02.002

25. De Azambuja E., Cardoso F., de Castro G. et al. Ki-67 as prognostic marker in early breast cancer: a meta-analysis of published studies involving 12,155 patients. Brit. J. Cancer, 2007, vol. 96,no.10, pp.1504-1513. doi:10.1038/sj.bjc.6603756

26. Li F.Y., Wu S.G., Zhou J. et al. Prognostic value of Ki-67 in breast cancer patients with positive axillary lymph nodes: a retrospective cohort study. Plos One, 2014, vol. 9, no.2, e87264. doi:10.1371/ journal.pone.0087264

27. Luporsi E., Andre F., Spyratos F. et al. Ki-67: level of evidence and methodological considerations for its role in the clinical management of breast cancer: analytical and critical review. Breast Cancer Res. Treat., 2012, vol.132, no. 3, pp. 895-915. doi: 10.1007/ s10549-011-1837-Z

28. Goldhirsch A., Ingle J.N., Gelber R.D. et al. Thresholds for therapies: highlights of the St Gallen International Expert Consensus on the primary therapy of early breast cancer. Ann. Oncol., 2009, vol.20, no. 8, pp.1319-1329. doi: 10.1093/annonc/mdp322

29. Dowsett M., Nielsen T., A'Hern R. et al. Assessment of Ki67 in breast cancer: recommendations from the International Ki67 in Breast Cancer working group. J. Natl. Cancer Inst., 2011, vol.103,no.22 , pp.1656-64. doi: 10.1093/jnci/djr393.

30. Kubbutat M., Key G., Duchrow M. et al. Epitope analysis of antibodies recognising the cell proliferation associated nuclear antigen previously defined by the antibody Ki-67 (Ki-67 protein). J. Clin Pathol ., 1994, vol.47, no.6,pp. 524-528. doi: 10.1136/ jcp.47.6.524

31. Cattoretti G., Becker M., Key G. et al. Monoclonal antibodies against recombinant parts of the Ki-67 antigen (MIB- 1 and MIB- 3 ) detect proliferating cells in microwave-processed formalin-fixed paraffin sections. Journal of Pathology, 1992,vol. 168. no.4, pp. 357-363 doi: 10.1002/path.1711680404

32. Key G, Becker MHG, Baron B, et al. New Ki67 equivalent murine monoclonal antibodies (MIB 1-3) generated against bacterially expressed parts of the Ki-67 cDNA containing three 66 bp repetitive elements encoding for the Ki-67 epitope. Lab Invest, 1993, vol.68,no.6, pp.629-636. PMID: 7685843

33. Lindboe C., Torp S. Comparison of Ki-67 equivalent antibodies. J. Clin. Pathol., 2002, vol.55, no.6, pp.467-471. doi: 10.1136/jcp.55.6.467

34. Zabaglo L, Salter J, Anderson H, et al. Comparative validation of the SP6 antibody to Ki67 in breast cancer. J Clin Pathol., 2010, vol.63,no.9, pp.800-804. doi : 10.1136/jcp.2010.07757

35. Viale G., Newel A., Walker E. et al. Ki-67 (30-9) scoring and differentiation in luminal A and luminal B breast cancer subtypes. Cancer Res., 2019, vol.79 (4 Suppl. Abstract PD2-11). doi:10.1158/15387445.SABCS18-PD2-11

36. Acs B., Kulka J., Kovacs A. et al. Comparison of five Ki67 antibodies regarding reproducibility and capacity to predict prognosis in breast cancer: Does the antibody matter?. Human Pathology, 2017, vol.65, pp.31-40, doi: 10.1016/j.humpath.2017.01.011

37. Nordic Immunohistochemical Quality Control (Ki67), 2016, assessments run B22. Available at: https://www.nordiqc.org (Accessed 12 July 2016).

38. Dodson A. Standardisation of Ki67 in breast cancer prognostication. 3rdNordiQC Conference on Applied Immunohistochemistry. 2017. Denmark. Available at: http://nordiqc2017.dk (Accessed 8 June 2017)

39. Polley M., Leung S., McShane L. et al. An International Ki67 Reproducibility Study. J. Natl. Cancer Inst., 2013,vol.105, no.24, pp.1897-1906. doi:10.1093/jnci/djt306

40. Polley M., Leung S., Gao D. et al. An international study to increase concordance in Ki67 scoring. Modern Pathology, 2015, vol.28, no.6, pp.778- 
786. doi: 10.1038/modpathol.2015.38

41. Leung S., Nielsen T., Zabaglo L. et al. Analytical validation of a standardized scoring protocol for Ki67: phase 3 of an international multicenter collaboration. Breast Cancer, 2016, vol.18, no.2, 16014; doi:10.1038/npjbcancer.2016.14

42. Penault-Llorca F., Radosevic-Robin N. Ki67 assessment in breast cancer: an update. Pathology, 2017, vol.49, no.2, pp. 166-171. doi: http://dx.doi. org/10.1016/j.pathol.2016.11.006

43. Gnant M, Thomssen C, Harbeck N. St. Gallen/Vienna 2015: A brief summary of the consensus discussion. Breast Care (Basel), 2015, vol.10,no.2, pp.124-130. doi.org/10.1159/000430488

44.Tashima R, Nishimura R, Osako T. et al. Evaluation of an optimal cut-off point for the Ki-67 index as a prognostic factor in primary breast cancer: a retrospective study. PLoS One, 2015, vol.10, no.7, e0119565. doi.org/10.1371/journal.pone.0119565

45. Petrelli F, Viale G, Cabiddu M, Barni S. Prognostic value of different cut-off levels of Ki-67 in breast cancer: a systematic review and meta-analy- sis of 64,196 patients. Breast Cancer Res Treat., 2015, vol.153,no.3, pp. 477-491. doi.org/10.1007/s10549015-3559-0

46. Bustreo S, Osella-Abate S, Cassoni P. et al. Optimal Ki67 cut-off for luminal breast cancer prognostic evaluation: a large case series study with a long-term follow-up. Breast Cancer Res Treat., 2016, vol.157, no.2,pp.363-371 doi.org/10.1007/s10549016-3817-9

47. Denkert C, Loibl S, Muller B. et al. Ki67 levels as predictive and prognostic parameters in pretherapeutic breast cancer core biopsies: a translational investigation in the neoadjuvant GeparTrio trial. Ann Oncol., 2013, vol.24, no.11, pp. 2786-2793. doi: 10.1093/annonc/mdt350

48. Koopman T., Buikema H., Hollema G.et al. Digital image analysis of Ki67 proliferation index in breast cancer using virtual dual staining on whole tissue sections: clinical validation and inter platform agreement. Breast Cancer Res. and Treat., 2018, vol.169, pp. 33-42. doi.org/10.1007/s10549018-4669-2 


\title{
КІ-67 БИОМАРКЕРІ ДЕНГЕЙІ НЕГІЗІНДЕ ЖАСУШАЛАРДЫН ПРОЛИФЕРАЦИЯСЫН БАҒАЛАУ
}

\author{
Жылқыбаев А.А., Сарина Н.И., Мун Е.А., Ескендірова С.3. \\ Ұлттық биотехнология орталыгы \\ Қорвалжын тас жолы, 13/5, Нұр-Сұлтан, 010000, Қазақстан \\ saule_e@mail.ru
}

\section{ТУЙІН}

Қазіргі уақытта жасушаның пролиферативті белсенділік деңгейін бағалаудың ең ақпараттық, қолжетімді және кең таралған әдісі - Кі-67 әмбебап биомаркер ақуызын анықтау болып табылады. Кі-67 антигені - ядролық матрицаның құрамдас бөлігі болып табылады және жасуша циклі кезінде оның ішкі ядролық оқшаулану өзгерістері байқалады. Кі-67 ақуызы негізінен хромосомалармен байланысады және митоз кезінде хромосомаларды қоршайтын перихромонуклеинді ақуыздар түріне жатады. Кі-67 ақуызы үлкен ядролық ақуыз ретінде cDNA кітапханасын клондау және жүйелеу арқылы сипатталды. Ол жасуша циклі кезінде конформациялық өзгерістерге ұшырайды. Кі-67 ақуызы митоз кезінде нуклеоплазмадан перихромосомалық қабатқа және кері қарай қозғалумен бірге фосфорлану арқылы посттрансляциялық модификациядан өтеді.

Аурудың нәтижесін және химиотерапияның тиімділігін болжауға қажетті бағалау әдістерін стандарттау мәселелері бар. Зерттеушілер біріншілік антиденелерді таңдауда, иммуногистохимиялық зерттеулерді жүргізу әдістерінде және экспрессияны есептеу жолына байланысты әртүрлі зертханалар арасындағы Кі-67 өзгергіштігінің жоғары индексін хабарлады.

Ki-67 экспрессиясының деңгейін анықтау сүт безі ісігінің молекулалық түрлерін ажыратуда маңызды рөл атқарады және химиотерапия сызбасын анықтайтын критерийлердің бірі болып табылады. Шекті мәндер деңгейлері үнемі белсенді талқылауда және Кі-67 шекті кесінді нүктесін анықтау аурудың гетерогенді биологиясына сәйкес келмейтіндігі көрсетілген. Сент-Галлен конференциясының 2015 жылғы соңғы ұсыныстарына сәйкес, терапияға жақсы жауап беру үшін төменгі, орташа және жоғары Кі-67 шегі анықталды. Осыған орай мақалада ақуыздың құрылымы мен қызметі, сонымен қатар Кі-67 стандартталған анықтау әдісі талқыланады.

Негізгі сөздер: Кі-67 биомаркері, жасушалардың пролиферациясы, пролиферативті белсенділік, сүт безінің қатерлі ісігі, ақуыздың экспрессиясы, иммундыгистохимия 


\title{
ОЦЕНКА КЛЕТОЧНОЙ ПРОЛИФЕРАЦИИ НА ОСНОВЕ УРОВНЯ БИОМАРКЕРА Кі-67
}

\author{
Жылкибаев А.А., Сарина Н.И., Мун Е.А., Ескендирова С.3. \\ Национальный иентр биотехнологии \\ Кургальжинское шоссе, 13/5, Нур-Султан, 010000, Казахстан \\ saule_e@mail.ru
}

\section{АБСТРАКТ}

На сегодняшний день самым информативным, доступным и распространенным методом оценки уровня пролиферативной активности клеток является выявление универсального биомаркера - белка Кі-67. Антиген Кі-67 является компонентом ядерного матрикса, при этом, в течение клеточного цикла наблюдаются изменения его внутриядерной локализации. Белок Кi-67 в основном связан с хромосомами и относится к семейству перихромонуклеиновых протеинов, окружающих хромосомы в течение митоза. Путем клонирования и секвенирования библиотеки кДНК белок Кі-67 характеризуется как крупный ядерный белок, подверженный выраженным конформационным изменениям в течение клеточного цикла. Белок Кі-67 претерпевает посттрансляционные модификации путем фосфорилирования, сопровождающиеся заметнымперераспределением Кі-67 из нуклеоплазмы в перихромосомный слой и обратно в течение митоза.

Существует проблема стандартизации методов оценки, необходимых для интеграции биомаркера в прогнозирование исхода заболевания и эффективности химиотерапии. Исследователи сообщают о высокой вариабельности индекса Кі-67 между различными лабораториями, зависящей от выбора первичных антител, методики проведения иммуногистохимического исследования и способов подсчета экспрессии.

Определение уровня экспрессии Кі-67 играет важную роль в разграничении молекулярных подтипов рака молочной железы и является одним из критериев определения схемы химиотерапии. Об уровнях порогового значения постоянно ведутся активные дискуссии и показано, что определение одной точки отсечения Кi-67 не отражает гетерогенную биологию заболевания. В соответствии с последними рекомендациями согласительной конференции St. Gallen 2015 года определены низкий, средний и высокий пороговые значения Кі-67 для достижения лучшего ответа на терапию.

Ключевые слова: биомаркер Кі-67, клеточная пролиферация, пролиферативная активность, рак молочной железы, экспрессия белка, иммуногистохимия. 